\title{
MINERALS AND TRACE ELEMENTS IN CYSTIC FIBROSIS
}

\author{
Anastasiya Dykyy *
}

Trondheim, Norway

\begin{abstract}
Cystic fibrosis (CF) is a single gene disorder which affects multiple organs. Due to intestinal malabsorption, several micronutrients, such as minerals and trace elements (TE), are not adequately absorbed by CF patients. Most studies agree that CF patients have low blood selenium and iron. Copper was found elevated in nails of $\mathrm{CF}$ patients and zinc decreased while magnesium elevated in hair of affected. However, studies on the levels of these TE in blood of CF patients have reported controversial results. This is probably due to the fact that only few studies analysed large groups of affected and that there might be variation in TE levels depending on the age and ethnicity. Thus, a new, large scale study should be conducted in order to determine the levels of different TE in CF patients. This will allow supplementing the affected with the correct combination of minerals and thus increase their well-being.
\end{abstract}

KEYWORDS: cystic fibrosis, micronutrients, minerals, trace elements, imbalance, metabolic disorders.

\section{INTRODUCTION}

Cystic fibrosis $(\mathrm{CF})$ is an autosomal recessive disorder that affects multiple organs and results in a median survival age of 35 years (Braga, Almgren, 2013). In the United States, approximately 30000 people suffer from CF (O'Brien, et al., 2013). In Russia it is estimated that about 12000 people are affected, however, only about 2600 patients are recordedin the national CF-register (Kashirskaya, 2008). The low number of recognised patients is probably due to inadequate screening and diagnosis.

Cystic fibrosis is caused by one of about 2000 possible mutations in the cystic fibrosis transmembrane conductance regulator (CFTR) gene. The most predominant mutation, found in about $66 \%$ of patients is $\Delta F 508$, i.e. the deletion of the amino acid phenylalanine (F) at position 508 (Saleheen, Frossard, 2008). The protein encoded by the CFTR gene is responsible for the transport of chloride and sodium ions through the plasma membrane. Changes due to mutations in the influx and efflux of the ions result in analtered mucousosmolarity. This leads to blocked bronchial airways by the mucous and results in impaired breathing and bacterial infections (Siwamogsatham, et al., 2014). The pancreas is another organ greatly affected by CF. In pancreatic insufficiency, present in $85 \quad 90 \%$ of CF patients, the pancreatic ducts are blocked by thick mucus which hinders food digestion, especially of fat and absorption of nutrients (Dodge, Turck, 2006). Although pancreatic enzyme replacement therapy is common in CF affected, fat malabsorption still continues at a certain degree (Siwamogsatham, et al., 2014). This results in the development of severe deficiency of fat-soluble vitamins (A, D, E, and K) (Carr, McBratney, 2000) and

\footnotetext{
* Corresponding author:

Anastasiya Dykyy

E-mail: anastasiya.dykyy@biotech.ntnu.no
}

trace elements (Yadav, et al., 2014). It has been established that the nutrition status of CF patients correlates with their lung function and survival rate (Liou, et al., 2001; Gozdzik, et al., 2008). Thus it is important to understand to what deficiencies CF patients are prone to, in order to compensate for them and hence increase their life quality. In this review, the present knowledge of trace element deficiencies or excesses present in CF patients is going to be summarised.

\section{TRACE ELEMENTS}

Similarly to vitamins, trace elements (TE) are absorbed mostly in the intestine. However, although much attention has been paid to vitamin deficiency in CF patients, much less consideration has been given to a balanced trace element level in the patients. Indeed, while $81 \%$ of pancreatic insufficient patients were reported to regularly use fat-soluble vitamin supplements, only few chose to supplement their diet with TE (Hollander, et al., 2010).

Selenium (Se) is a TE known for its antioxidant function, as part of the active site of glutathione peroxidase (GPX). This protein is found in the cytosol and membranes, which protects the cell from oxidative stress (Portal, et al., 1993). It was suggested that $\mathrm{CF}$ patients are at risk of Se deficits due to the element malabsorption. In addition, this deficit maycontribute to the pathogenesis in the form of higher oxidative damage resulting in lipid peroxidation (Dworkin, et al., 1987). Most authors agree on a decreased Se level and GPX activity in a fraction of the CF population (Dworkin, et al., 1987). Others state that Se deficiency is only significant in CF children below the age of 6 (Ward, et al., 1984). Se deficiencies were also reported in hair of children and teenagers (Savrasova, et al., 2009). 
Zinc ( $\mathrm{Zn})$ is a TE that has an essential role in many organs which are affected in CF (Damphousse, et al., 2014). For instance, $\mathrm{Zn}$ is involved in the ciliary function, wound healing and has antioxidant function in the airways epithelium (Rottner, et al., 2011). $\mathrm{Zn}$ is also profusely found in the pancreas, where it is involved in glucagon secretion and insulin signalling (Kelleher, et al., 2011). CF related diabetes is characterised by decreased insulin sensitivity and secretion which is associated with $\mathrm{Zn}$ deficit (Costa, et al., 2005). The reported authors do not agree whether $\mathrm{Zn}$ levels are high, low or do not change in $\mathrm{CF}$ patients. However, most state that $\mathrm{Zn}$ levels are low in hair of CF patients (Kopito, Shwachman, 1964; Jacob, et al., 1978; Varkonyi, et al., 1992). Zn levels of $\mathrm{CF}$ patientsin cerumen were 16 times higher than in controls (Brand-Auraban, et al., 1972).

Copper $(\mathrm{Cu})$ is a TE involved in proper organ functioning and metabolic processes. Humans with $\mathrm{Cu}$ deficiency exhibit anaemia and neutropenia (Danks, 1988), while animal experiments have shown $\mathrm{Cu}$ deficiency to eventually lead to connective tissue impairment (Medeiros, et al., 1993), pancreatic atrophy (Weaver, et al., 1988) and an impaired immune system (Lukasewycz, Prohaska, 1990).Authors do not agree on $\mathrm{Cu}$ levels in blood. Some claim they are decreased, some elevated, while others detect no difference compared to control levels (Table). $\mathrm{Cu}$ levels were found elevated in nails of CF patients (van Stekelenburg, et al. 1975; Escobar, et al., 1980).

\section{Table. Results of the investigations of macro- and trace elements levels in the blood, if not stated otherwise, of CF patients compared to controls}

\begin{tabular}{|c|c|c|c|c|}
\hline Indication & $\begin{array}{c}\text { Number } \\
\text { of patients }\end{array}$ & $\begin{array}{l}\text { Age, } \\
\text { years }\end{array}$ & Summary of results & Source \\
\hline \multicolumn{5}{|c|}{ Selenium (Se) } \\
\hline \multirow{10}{*}{$\begin{array}{l}\text { Decreased } \\
\text { levels }\end{array}$} & 15 & - & $\begin{array}{l}\text { In } 29 \% \text { and } 33 \% \text { of CF patients in plasma and red blood } \\
\text { cells (RBC) respectively }\end{array}$ & $\begin{array}{c}\text { (Dworkin, et al., } \\
\text { 1987) }\end{array}$ \\
\hline & 6 & Children & Very low in plasma and RBC of not supplemented children & (Foucaud, et al., 1988) \\
\hline & 20 & Children & $\begin{array}{l}\text { Mild deficiency in plasma and RBC of children } \\
\text { with pancreatic enzyme replacement }\end{array}$ & $\begin{array}{c}\text { (Foucaud, et al., } \\
1988 \text { ) }\end{array}$ \\
\hline & 20 & $7-19$ & In plasma and $\mathrm{RBC}$ & (Neve, et al., 1983a) \\
\hline & 20 & $7-19$ & In plasma and RBC & (Neve, et al., 1983b) \\
\hline & 14 & $2-19$ & In plasma & (Richard, et al., 1990) \\
\hline & 13 & $6-15$ & In plasma & $\begin{array}{l}\text { (van Caillie-Bertrand, } \\
\text { et al., 1982) }\end{array}$ \\
\hline & 20 & $19-34$ & In serum & (Stead, et al., 1985) \\
\hline & 31 & $3-35$ & In serum & (Michalke, 2004) \\
\hline & 15 & $0-14$ & - & (Ward, et al., 1984) \\
\hline No difference & 27 & $7-20$ & In plasma & (Portal, et al., 1993) \\
\hline \multirow{4}{*}{$\begin{array}{l}\text { Decreased } \\
\text { GPX levels }\end{array}$} & 14 & $2-19$ & In plasma and $\mathrm{RBC}$ & (Richard, et al., 1990) \\
\hline & 6 & - & Very low levels in untreated children & (Foucaud, et al., 1988) \\
\hline & 20 & - & $\begin{array}{l}\text { Mild deficiency in children with pancreatic enzyme } \\
\text { replacement }\end{array}$ & (Foucaud, et al., 1988) \\
\hline & 15 & $0-14$ & Significant decrease in children below the age of 6 & (Ward, et al., 1984) \\
\hline No difference & 13 & $10-22$ & - & (Percival, et al., 1995) \\
\hline $\begin{array}{l}\text { Se levels } \\
\text { in other } \\
\text { analytes }\end{array}$ & - & $1-18$ & $\begin{array}{l}\text { Decreased Se levels in hair of CF patient } \\
\text { from Stavropol region, Russia }\end{array}$ & (Dworkin, et al., 1987) \\
\hline \multicolumn{5}{|c|}{ Zinc $(\mathrm{Zn})$} \\
\hline \multirow{4}{*}{$\begin{array}{l}\text { Decreased } \\
\text { levels }\end{array}$} & 40 & $1-46$ & In plasma of $10 \%$ of CF patients & (Akanli, et al., 2003) \\
\hline & 15 & $\begin{array}{c}\text { Mean } 1.8 \\
\text { months }\end{array}$ & In plasma of $30 \%$ of $\mathrm{CF}$ patients & (Krebs, et al., 2000) \\
\hline & 27 & $\begin{array}{c}\text { months- } \\
12 \text { years } \\
\end{array}$ & In $96 \%$ of North Indian CF children & (Yadav, et al., 2014) \\
\hline & 304 & $18-66$ & In plasma of $22 \%$ of patients with moderate lung disease & $\begin{array}{l}\text { (Damphousse, et al., } \\
\text { 2014) }\end{array}$ \\
\hline
\end{tabular}




\begin{tabular}{|c|c|c|c|c|}
\hline & 13 & $2-19$ & In plasma & $\begin{array}{l}\text { (Safai-Kutti, et al., } \\
\text { 1991) }\end{array}$ \\
\hline & 20 & $7-19$ & $\begin{array}{l}\text { In plasma of patients with moderate-severe growth } \\
\text { retardation and severe pulmonary disease }\end{array}$ & (Neve, et al., 1983b) \\
\hline & 14 & $2-19$ & In serum & (Richard, et al., 1990) \\
\hline & 51 & $1-46$ & In RBC of $31 \%$ of CF patients & (Akanli, et al., 2003) \\
\hline \multirow{2}{*}{$\begin{array}{c}\text { Elevated } \\
\text { levels }\end{array}$} & 20 & $7-19$ & In $\mathrm{RBC}$ & (Neve, et al., 1983a) \\
\hline & 20 & $7-19$ & In RBC & (Neve, et al., 1983b) \\
\hline \multirow{8}{*}{ No difference } & 18 & $6-17$ & In plasma, decreases with age & (Jacob, et al., 1978) \\
\hline & 20 & $7-19$ & In plasma of relatively healthy CF patients & (Neve, et al., 1983b) \\
\hline & 15 & $5-22$ & In plasma and $\mathrm{RBC}$ & $\begin{array}{l}\text { (Vormann, et al., } \\
\text { 1992) }\end{array}$ \\
\hline & 62 & $8-11$ & In plasma & $\begin{array}{l}\text { (Maqbool, et al., } \\
\text { 2006) }\end{array}$ \\
\hline & 13 & $10-22$ & - & (Percival, et al., 1995) \\
\hline & 13 & $6-15$ & In serum & $\begin{array}{l}\text { (van Caillie-Bertrand, } \\
\text { et al., 1982) }\end{array}$ \\
\hline & 101 & Mean 16 & In serum & $\begin{array}{l}\text { (Van Biervliet, et al., } \\
\text { 2007) }\end{array}$ \\
\hline & 117 & - & In serum & $\begin{array}{l}\text { (Kelleher, et al., } \\
\text { 1986) }\end{array}$ \\
\hline \multirow{10}{*}{$\begin{array}{l}\text { Zn levels } \\
\text { in other } \\
\text { analytes }\end{array}$} & 18 & $6-17$ & Decreased $\mathrm{Zn}$ levels in hair & (Jacob, et al., 1978) \\
\hline & 9 & - & Decreased Zn levels in hair & $\begin{array}{c}\text { (Varkonyi, et al., } \\
\text { 1992) }\end{array}$ \\
\hline & 30 & - & Decreased $\mathrm{Zn}$ levels in hair and nails & $\begin{array}{l}\text { (Kopito, Shwachman, } \\
\text { 1964) }\end{array}$ \\
\hline & - & - & Elevated $\mathrm{Zn}$ levels in nails & (Escobar, et al., 1980) \\
\hline & 23 & - & Elevated $\mathrm{Zn}$ levels in sputum & (Gray, et al., 2010) \\
\hline & 52 & Children & Elevated $\mathrm{Zn}$ levels in sputum & (Sirotkin, 1999) \\
\hline & 35 & $4-21$ & No difference in $\mathrm{Zn}$ levels in submandibular saliva & $\begin{array}{l}\text { (Blomfield, et al., } \\
\text { 1973) }\end{array}$ \\
\hline & 52 & Children & $\begin{array}{l}\text { Elevated } \mathrm{Zn} \text { levels in urine of CF patients with } \\
\text { pulmonary heart disease }\end{array}$ & (Sirotkin, 1999) \\
\hline & 20 & $7-30$ & Elevated $\mathrm{Zn}$ levels in the exhaled air condensate & (Griese, et al., 2003) \\
\hline & 7 & $11-17$ & Elevated (16 times higher) Zn levels in cerumen & $\begin{array}{l}\text { (Brand-Auraban, et } \\
\text { al., 1972) }\end{array}$ \\
\hline \multicolumn{5}{|c|}{ Copper $(\mathrm{Cu})$} \\
\hline $\begin{array}{l}\text { Decreased } \\
\text { levels }\end{array}$ & 27 & $\begin{array}{l}3 \text { months- } \\
12 \text { years }\end{array}$ & In $44 \%$ of North Indian CF children & (Yadav, et al., 2014) \\
\hline \multirow{4}{*}{$\begin{array}{l}\text { Elevated } \\
\text { levels }\end{array}$} & 20 & $7-19$ & In RBC & (Neve, et al., 1983a) \\
\hline & 20 & $7-19$ & In RBC & (Neve, et al., 1983b) \\
\hline & 7 & $19-32$ & In plasma & (Percival, et al.,, 1999) \\
\hline & 18 & $6-18$ & In plasma & $\begin{array}{l}\text { (Solomons, et al.,, } \\
1981 \text { ) }\end{array}$ \\
\hline \multirow{4}{*}{ No difference } & 13 & $10-22$ & - & (Percival, et al., 1995) \\
\hline & 20 & $7-19$ & In plasma & (Neve, et al., 1983b) \\
\hline & 117 & - & In serum & $\begin{array}{c}\text { (Kelleher, et al., } \\
\text { 1986) }\end{array}$ \\
\hline & 13 & $6-15$ & In serum & $\begin{array}{l}\text { (van Caillie-Bertrand, } \\
\text { et al., 1982) }\end{array}$ \\
\hline
\end{tabular}




\begin{tabular}{|c|c|c|c|c|}
\hline \multirow{7}{*}{$\begin{array}{l}\mathrm{Cu} \text { levels } \\
\text { in other } \\
\text { analytes }\end{array}$} & 9 & - & No difference in $\mathrm{Cu}$ levels in hair & $\begin{array}{l}\text { (Varkonyi, et al., } \\
\text { 1992) }\end{array}$ \\
\hline & - & - & Elevated $\mathrm{Cu}$ levels in nails & (Escobar, et al., 1980) \\
\hline & 36 & Children & Elevated $\mathrm{Cu}$ levels in nails & $\begin{array}{l}\text { (van Stekelenburg, } \\
\text { et al., 1975) }\end{array}$ \\
\hline & 23 & - & Elevated $\mathrm{Cu}$ levels in sputum & (Gray, et al., 2010) \\
\hline & 35 & $4-21$ & No difference in $\mathrm{Cu}$ levels in submandibular saliva & $\begin{array}{l}\text { (Blomfield, et al., } \\
\text { 1973) }\end{array}$ \\
\hline & 13 & $6-15$ & Elevated $\mathrm{Cu}$ levels in urine & $\begin{array}{l}\text { (van Caillie-Bertrand, } \\
\text { et al., 1982) }\end{array}$ \\
\hline & 16 & $0-20$ & Decreased $\mathrm{Cu}$ levels in pancreas & $\begin{array}{l}\text { (Kopito, Shwachman, } \\
\text { 1976) }\end{array}$ \\
\hline \multicolumn{5}{|c|}{ Iron $(\mathrm{Fe})$} \\
\hline \multirow{5}{*}{$\begin{array}{l}\text { Decreased } \\
\text { levels }\end{array}$} & 27 & $\begin{array}{c}3 \text { months- } \\
12 \text { years }\end{array}$ & In $48 \%$ of North Indian CF children & (Yadav, et al., 2014) \\
\hline & 14 & $2-19$ & - & (Richard, et al., 1990) \\
\hline & 18 & $6-18$ & In plasma & $\begin{array}{l}\text { (Solomons, et al., } \\
\text { 1981) }\end{array}$ \\
\hline & 15 & $5-22$ & In plasma & (Vormann, et al., 1992) \\
\hline & 117 & & In serum & (Kelleher, et al., 1986) \\
\hline No difference & 7 & $19-32$ & In plasma & (Percival, et al., 1999) \\
\hline \multirow{3}{*}{$\begin{array}{l}\text { Fe levels } \\
\text { in other } \\
\text { analytes }\end{array}$} & 9 & - & No difference in Fe levels in hair & $\begin{array}{c}\text { (Varkonyi, et al., } \\
\text { 1992) }\end{array}$ \\
\hline & - & $1-3$ & Decreased Fe levels in hair & (Savrasova, 2009) \\
\hline & 52 & Children & Elevated Fe levels in sputum & (Sirotkin, 1999) \\
\hline \multicolumn{5}{|c|}{ Magnesium (Mg) } \\
\hline \multirow{2}{*}{$\begin{array}{c}\text { No difference } \\
\text { in Mg blood } \\
\text { levels }\end{array}$} & 15 & $5-22$ & In plasma and $\mathrm{RBC}$ & $\begin{array}{c}\text { (Vormann, et al., } \\
\text { 1992) }\end{array}$ \\
\hline & 117 & - & In serum & $\begin{array}{l}\text { (Kelleher, et al., } \\
\text { 1986) }\end{array}$ \\
\hline \multirow{5}{*}{$\begin{array}{l}\text { Mg levels } \\
\text { in other } \\
\text { analytes }\end{array}$} & 30 & - & Elevated $\mathrm{Mg}$ levels in hair and nails & $\begin{array}{c}\text { (Kopito, Shwachman, } \\
\text { 1964) }\end{array}$ \\
\hline & - & $4-6$ & $\begin{array}{l}\text { Elevated } \mathrm{Mg} \text { levels in hair of CF patient } \\
\text { from Stavropol region, Russia }\end{array}$ & (Savrasova, 2009) \\
\hline & 35 & $4-21$ & No difference in $\mathrm{Mg}$ levels in submandibular saliva & $\begin{array}{c}\text { (Blomfield, et al., } \\
1973)\end{array}$ \\
\hline & 7 & $11-17$ & Elevated $\mathrm{Mg}$ levels in cerumen & $\begin{array}{l}\text { (Brand-Auraban, et } \\
\text { al., 1972) }\end{array}$ \\
\hline & 16 & $0-20$ & Decreased $\mathrm{Mg}$ levels in pancreas & $\begin{array}{l}\text { (Kopito, Shwachman, } \\
\text { 1976) }\end{array}$ \\
\hline \multicolumn{5}{|c|}{ Calcium $(\mathrm{Ca})$} \\
\hline $\begin{array}{l}\text { No difference } \\
\text { in blood }\end{array}$ & 117 & - & No difference in $\mathrm{Ca}$ levels in serum & $\begin{array}{c}\text { (Kelleher, et al., } \\
\text { 1986) }\end{array}$ \\
\hline \multirow{4}{*}{$\begin{array}{l}\text { Ca levels } \\
\text { in other } \\
\text { analytes }\end{array}$} & 9 & - & No difference in $\mathrm{Ca}$ levels in hair & $\begin{array}{c}\text { (Varkonyi, et al., } \\
\text { 1992) }\end{array}$ \\
\hline & 35 & $4-21$ & Elevated $\mathrm{Ca}$ levels in submandibular saliva & $\begin{array}{c}\text { (Blomfield, et al., } \\
\text { 1973) }\end{array}$ \\
\hline & 7 & $11-17$ & Elevated (6 times higher) $\mathrm{Ca}$ levels in cerumen & $\begin{array}{l}\text { (Brand-Auraban, et } \\
\text { al., 1972) }\end{array}$ \\
\hline & 16 & $0-20$ & $\begin{array}{l}\text { Elevated Ca levels ( } 10 \text { times higher) in obstructed ductal } \\
\text { structures in pancreas, with Ca deficit in adjacent regions }\end{array}$ & $\begin{array}{l}\text { (Kopito, Shwachman, } \\
\text { 1976) }\end{array}$ \\
\hline
\end{tabular}




\begin{tabular}{|c|c|c|c|c|}
\hline \multicolumn{5}{|c|}{ Potassium $(\mathrm{K})$} \\
\hline \multirow{7}{*}{$\begin{array}{l}\text { K levels } \\
\text { in other } \\
\text { analytes }\end{array}$} & 9 & - & No difference in $\mathrm{K}$ levels in hair & $\begin{array}{l}\text { (Varkonyi, et al., } \\
\text { 1992) }\end{array}$ \\
\hline & 22 & $\begin{array}{l}2 \text { months- } \\
9 \text { years }\end{array}$ & No difference in $\mathrm{K}$ levels in nails & $\begin{array}{l}\text { (Antonelli, et al., } \\
\text { 1969) }\end{array}$ \\
\hline & 30 & - & Elevated $\mathrm{K}$ levels in hair and nails & $\begin{array}{l}\text { (Kopito, Shwachman, } \\
\text { 1964) }\end{array}$ \\
\hline & 4 & - & Elevated $\mathrm{K}$ levels (1-3 times) in eccrine sweat & $\begin{array}{l}\text { (Kopito, Shwachman, } \\
\text { 1964) }\end{array}$ \\
\hline & 35 & $4-21$ & No difference in $\mathrm{K}$ levels in submandibular saliva & $\begin{array}{l}\text { (Blomfield, et al., } \\
\text { 1973) }\end{array}$ \\
\hline & 7 & $11-17$ & Elevated $\mathrm{K}$ levels in cerumen & $\begin{array}{l}\text { (Brand-Auraban, et } \\
\text { al., 1972) }\end{array}$ \\
\hline & 16 & $0-20$ & Decreased $\mathrm{K}$ levels in pancreas & $\begin{array}{l}\text { (Kopito, Shwachman, } \\
\text { 1976) }\end{array}$ \\
\hline \multicolumn{5}{|c|}{ Sodium $(\mathrm{Na})$} \\
\hline \multirow{6}{*}{$\begin{array}{l}\text { Na levels } \\
\text { in other } \\
\text { analytes }\end{array}$} & 4 & - & Elevated $\mathrm{Na}$ levels (2-5 times) in eccrine sweat & $\begin{array}{l}\text { (Kopito, Shwachman, } \\
\text { 1964) }\end{array}$ \\
\hline & 30 & - & Elevated $\mathrm{Na}$ levels in hair and nails & $\begin{array}{l}\text { (Kopito, Shwachman, } \\
\text { 1964) }\end{array}$ \\
\hline & 22 & $\begin{array}{l}2 \text { months- } \\
9 \text { years }\end{array}$ & Elevated $\mathrm{Na}$ levels in nails & $\begin{array}{l}\text { (Antonelli, et al., } \\
\text { 1969) }\end{array}$ \\
\hline & 35 & $4-21$ & Elevated $\mathrm{Na}$ levels in submandibular saliva & $\begin{array}{c}\text { (Blomfield, et al., } \\
\text { 1973) }\end{array}$ \\
\hline & 20 & $7-30$ & No difference in Na levels in the exhaled air condensate & (Griese, et al., 2003) \\
\hline & 16 & $0-20$ & Decreased $\mathrm{Na}$ levels in pancreas & $\begin{array}{l}\text { (Kopito, Shwachman, } \\
\text { 1976) }\end{array}$ \\
\hline \multicolumn{5}{|c|}{ Chlorine $(\mathrm{Cl})$} \\
\hline \multirow{3}{*}{$\begin{array}{l}\mathrm{Cl} \text { levels } \\
\text { in other } \\
\text { analytes }\end{array}$} & 9 & - & No difference in $\mathrm{Cl}$ levels in hair & $\begin{array}{c}\text { (Varkonyi, et al., } \\
\text { 1992) }\end{array}$ \\
\hline & 35 & $4-21$ & Elevated $\mathrm{Cl}$ levels in submandibular saliva & $\begin{array}{l}\text { (Blomfield, et al., } \\
\text { 1973) }\end{array}$ \\
\hline & 20 & $7-30$ & No difference in $\mathrm{Cl}$ levels in the exhaled air condensate & (Griese, et al., 2003) \\
\hline \multicolumn{5}{|c|}{ Cobalt (Co) } \\
\hline $\begin{array}{l}\text { Co levels } \\
\text { in other } \\
\text { analytes }\end{array}$ & - & $1-18$ & $\begin{array}{l}\text { Decreased Co levels in hair of CF patient from Stavropol } \\
\text { region, Russia }\end{array}$ & (Savrasova, 2009) \\
\hline \multicolumn{5}{|c|}{ Strontium $(\mathrm{Sr})$} \\
\hline $\begin{array}{c}\text { Elevated } \\
\text { levels in blood }\end{array}$ & 52 & Children & Elevated Sr levels in serum & (Sirotkin, 1999) \\
\hline \multirow{2}{*}{$\begin{array}{l}\text { Srlevels } \\
\text { in other } \\
\text { analytes }\end{array}$} & 52 & Children & Elevated Sr levels in sputum & (Sirotkin, 1999) \\
\hline & 52 & Children & $\begin{array}{l}\text { Elevated Sr levels in urine of CF patients with pulmo- } \\
\text { nary heart disease }\end{array}$ & (Sirotkin, 1999) \\
\hline \multicolumn{5}{|c|}{ Manganese (Mn) } \\
\hline \multirow{2}{*}{$\begin{array}{l}\text { Mnlevels } \\
\text { in other } \\
\text { analytes }\end{array}$} & 30 & - & Elevated Mn levels in hair and nails & $\begin{array}{l}\text { (Kopito, Shwachman, } \\
\text { 1964) }\end{array}$ \\
\hline & - & $1-18$ & $\begin{array}{l}\text { Decreased Mn levels in hair of CF patient from Stavro- } \\
\text { pol region, Russia }\end{array}$ & (Savrasova, 2009) \\
\hline \multicolumn{5}{|c|}{ Chromium (Cr) } \\
\hline $\begin{array}{l}\text { Crlevels } \\
\text { in other } \\
\text { analytes }\end{array}$ & 52 & Children & $\begin{array}{l}\text { Elevated } \mathrm{Cr} \text { levels in urine of } \mathrm{CF} \text { patients with pulmo- } \\
\text { nary heart disease }\end{array}$ & (Sirotkin, 1999) \\
\hline
\end{tabular}


Most of the body iron $(\mathrm{Fe})$ reserve $(70 \%)$ is located in erythrocytes, while $25 \%$ of it is found in ferritin and haemosiderin in the liver, spleen and bone marrow (Sinaasappel, et al., 2002). The level of Fe is usually measured as the amount of ferritin in serum. However, as ferritin concentration might increase with infection, CF patients' Fe levels greatly vary (Sinaasappel, et al., 2002). Fe levels were found by most authors to be decreased in the blood of CF patients.

Magnesium $(\mathrm{Mg})$ participates in various processes of the skeleton and muscular development (Sinaasappel, et al., 2002). In addition, Mg deficits increase oxidative damage (Spasov, et al., 2012), which is already at high levels in CF patients (Dworkin, et al., 1987). Although no decreased $\mathrm{Mg}$ levels were found in the summarised studies, cases with hypomagnesaemia due to excessive renal loss of $\mathrm{Mg}$ have been reported in children affected with CF (Akbar, et al., 1989). Mg levels have been found elevated in hair of CF patients (Kopito, Shwachman, 1964; Savrasova, et al., 2009).

Less knowledge has been accumulated on the levels of other TE in CF patients and thus their levels in patients will have to be confirmed in future investigations.

\section{CONCLUSION}

The abovementioned studies show that there is still no consensus on which TE CF patients are deficient of. Most studies agree on the deficiency of Se and $\mathrm{Fe}$ in blood of $\mathrm{CF}$ patients. Findings regarding $\mathrm{Zn}, \mathrm{Cu}, \mathrm{Mg}$ and other TE are more controversial. In this literature review only one work was found that comprehensively analysed all TE in different organs (Kopito, Shwachman, 1964). It is now time to repeat such work using more precise techniques and larger groups of patients in order to finally shed some light in what minerals $\mathrm{CF}$ patients have deficits and in what tissues.

\section{REFERENCES}

Akanli L., Lowenthal D.B., Gjonaj S., Dozor A.J. Plasma and red blood cell zinc in cystic fibrosis. Pediatric Pulmonology. 2003, 35(1):2-7.

Akbar A., Rees J.H.M., Nyamugunduru G., English M.W., Spencer D.A., Wetter P.H. Aminoglycosideassociated hypomagnesaemia in children with cystic fibrosis. Acta Paediatr. 1999. 88(7):783-5.

Antonelli M., Ballati G., Annibaldi L. Simplified nail clipping test for diagnosis of cystic fibrosis. Arch Dis Child. 1969, 44(234):218-20.

Blomfield J., Warton K.L., Brown J.M. Flow rate and inorganic components of submandibular saliva in cystic fibrosis. Arch Dis Child. 1973, 48(4):267-74.

Braga S.F., Almgren M.M. Complementary therapies in cystic fibrosis: nutritional supplements and herbal products. J Pharm Pract. 2013, 26(1):14-7.

Brand-Auraba, A., Kopito L., Shwachman H. Chemical analysis of some inorganic elements in cerumen from pa- tients with cystic fibrosis. J Investig Dermatol. 1972, 58(1):14-15.

Carr S.B. McBratney J. The role of vitamins in cystic fibrosis. J R Soc Med, 2000, 93(Suppl 38):14-9.

Costa M., Potvin S., Berthiaume Y., Gauthier L., Jeanneret A., Lavoie A., Levesque R., Chiasson J.L., Rabasa-Lhoret R. Diabetes: A major co-morbidity of cystic fibrosis. Diabetes and Metabolism. 2005, 31 (3 I):221-232.

Damphousse V., Mailhot M., Berthiaume Y., RabasaLhoret R., Mailhot G. Plasma zinc in adults with cystic fibrosis: correlations with clinical outcomes. J Trace Elem Med Biol. 2014, 28(1):60-4.

Dank, D.M. Copper deficiency in humans. Annu Rev Nutr. 1988, 8:235-57

Dodge J.A., Turck D. Cystic fibrosis: nutritional consequences and management. Best Pract Res Clin Gastroenterol. 2006, 20(3):531-46.

Dworkin B., Newman L.J., Berezin S., Rosenthal W.S., Schwarz S.M., Leiss L. Low blood selenium levels in patients with cystic fibrosis compared to controls and healthy adults. JPEN J Parenter Enteral Nutr. 1987, 11(1):38-41.

Escobar H., Arroyo M, Suárez L., Camarero C., Crespo E., Vera C. Copper and zinc levels in nails of children with cystic fibrosis, carriers and healthy controls (author's transl). An Esp Pediatr. 1980, 13(2):127-32.

Foucaud, P., Therond P., Marchand M., Brion F., Demelier J.F., Navarro J. Selenium and vitamin E in mucoviscidosis. Arch Fr Pediatr. 1988, 45(6):383-6.

Gozdzik, J., Cofta S., Piorunek T., Batura-Gabryel H., Kosicki J. Relationship between nutritional status and pulmonary function in adult cystic fibrosis patients. J Physiol Pharmacol. 2008, 59(Suppl 6):253-60.

Gray R.D., Duncan A., Noble D., Imrie M., O'Reilly D.S., Innes J.A., Porteous D.J., Greening A.P., Boyd A.C. Sputum trace metals are biomarkers of inflammatory and suppurative lung disease. Chest. 2010, 137(3):635-41.

Griese M., Noss J., Schramel P. Elemental and ion composition of exhaled air condensate in cystic fibrosis. J Cyst Fibros. 2003, 2(3):136-42.

Hollander F.M., de Roos N.M., Dopheide J., Hoekstra T., van Berkhout F.T. Self-reported use of vitamins and other nutritional supplements in adult patients with cystic fibrosis. Is daily practice in concordance with recommendations?. International Journal for Vitamin and Nutrition Research. 2010, 80(6):408-415.

Jacob, R.A., Sandstead H.H., Solomons N.W., Rieger C., Rothberg R. Zinc status and vitamin A transport in cystic fibrosis. American Journal of Clinical Nutrition. 1978, 31(4):638-644.

Kashirskaya N., Tolstova V., Kapranov N. Cystic fibrosis is the national priority programs in the Russian Federation 2008. Pediatria. 2008, 87(4):6-14.

Kelleher J., Goode H.F., Field H.P., Walker B.E., Miller M.G., Littlewood J.M. Essential element nutritional status in cystic fibrosis. Hum Nutr Appl Nutr. 1986, 40(2):79-84.

Kelleher S.L., McCormick N.H., Velasquez V., LopezRottner V. Zinc in specialized secretory tissues: Roles in the pancreas, prostate, and mammary gland. Advances in Nutrition. 2011, 2(2):101-111.

Kopito L., Shwachman H. Spectroscopic Analysis of Tissues from Patients with Cystic Fibrosis and Controls. Nature. 1964, 202(4931):501-502. 
Kopito L.E., Shwachman H. The pancreas in cystic fibrosis: chemical composition and comparative morphology. Pediatr Res. 1976, 10(8):742-9.

Krebs N.F., Westcott J.E., Arnold T.D., et al. Abnormalities in zinc homeostasis in young infants with cystic fibrosis. Pediatr Res. 2000, 48(2):256-61.

Liou T.G., Adler F.R., FitzSimmons S.C., Cahill B.C., Hibbs J.R., Marshall B.C. Predictive 5-Year Survivorship Model of Cystic Fibrosis. American Journal of Epidemiology. 2001, 153(4):345-352.

Lukasewycz O.A., Prohaska J.R. The immune response in copper deficiency. Ann N Y Acad Sci. 1990, 587:147-59.

Maqbool A., Schall J.I., Zemel B.S., Garcia-Espana J.F., Stallings V.A. Plasma zinc and growth status in preadolescent children with cystic fibrosis. Journal of Pediatric Gastroenterology and Nutrition. 2006, 43(1):95-101.

Medeiros D.M., Davidson J., Jenkins J.E. A unified perspective on copper deficiency and cardiomyopathy. Proc Soc Exp Biol Med. 1993, 203(3):262-73.

Michalke B. Selenium speciation in human serum of cystic fibrosis patients compared to serum from healthy persons. J Chromatogr A. 2004, 1058(1-2):203-8.

Neve J., Molle L., Hanocq M., Sinet P.M., Van Geffel R. Erythrocyte and plasma trace element levels in clinical assessments : Zinc, copper, and selenium in normals and patients with Down's syndrome and cystic fibrosis. Biol Trace Elem Res. 1983a, 5(2):75-9.

Neve J., Van Geffel R., Hanocq M., Molle L. Plasma and erythrocyte zinc, copper and selenium in cystic fibrosis. Acta Paediatr Scand. 1983b, 72(3):437-40.

O'Brien C.E., Harden H., Com G. A survey of nutrition practices for patients with cystic fibrosis. Nutr Clin Pract. 2013, 28(2):237-41

Percival S.S., Bowser E., Wagner M. Reduced copper enzyme activities in blood cells of children with cystic fibrosis The American Journal of Clinical Nutrition. 1995, 62(3):633-8.

Percival S.S., Kauwell G.P., Bowser E., Wagner M. Altered copper status in adult men with cystic fibrosis. J Am Coll Nutr. 1999, 18(6):614-9.

Portal B., Richard M.J., Ducros V., Aguilaniu., Brunel F., Faure H., Gout J.P., Bost M., Favier A. Effect of doubleblind crossover selenium supplementation on biological indices of selenium status in cystic fibrosis patients. Clin Chem. 1993, 39(6):1023-8.

Richard, M.J., et al. Selenium and oxidant injury in patients with cystic fibrosis. Adv Exp Med Biol. 1990, 264:175-8.

Rottner M., Tual-Chalot S., Mostefai H.A., Andriantsitohaina R., Freyssinet J.M., Martínez M.C. Increased oxidative stress induces apoptosis in human cystic fibrosis cells. PLoS One, 2011. 6(9): p. e24880.

Safai-Kutti S., Selin E., Larsson S.,et al. Zinc therapy in children with cystic fibrosis. Beitr Infusionsther. 1991, 27:104-14

Saleheen D. Frossard P.M. The cradle of the delta F508 mutation. J Ayub Med Coll Abbottabad. 2008, 20(4):157-60.
Savrasova Y.S., Dubovoi R.M., Vodovozova. E.V. Peculiarities of mineral status of children with cystic fibrosis in the stavropol territor. Trace Elements in Medicine. 2009, 10(3):100-101.

Sinaasappel M., Stern M., Littlewood J., Wolfe S., Steinkamp G., Heijerman H.G.M., Robberecht., Doring G. Nutrition in patients with cystic fibrosis: a European Consensus. Journal of Cystic Fibrosis. 2002, 1(2):51-75.

Sirotkin E.A. Clinical-genetic peculiarities of cystic fibrosis and trace elements. Pediatria. 1999, 6:4.

Siwamogsatham O, Dong W., Binongo J.N., Chowdhury R., Alvarez J.A., Feinman S.J., Enders J., Tangpri cha V. Relationship Between Fat-Soluble Vitamin Supplementation and Blood Concentrations in Adolescent and Adult Patients With Cystic Fibrosis. Nutrition in Clinical Practice, 2014, 29(4):491-497.

Solomons N.W., Wagonfeld J.B., Rieger C., Jacob R.A., Bolt M., Horst J.V., Rothberg R., Sandstead H. Some biochemical indices of nutrition in treated cystic fibrosis patients. Am J Clin Nutr. 1981, 34(4):462-74.

Spasov A.A., Zheltova A.A., Kharitonov M.V. Magnesium and the oxidative stress. Ross Fiziol Zh Im I M Sechenova. 2012, 98(7):915-23.

Stead R., Redington A.N., Hinks L.J., Clayton B.E., Hodson M.E., Batten J.C. Selenium deficiency and possible increased risk of carcinoma in adults with cystic fibrosis. The Lancet. 1985, 326(8460):862-863.

van Biervliet S., Van Biervliet J.P., Vande Velde S., Robberecht E. Serum zinc concentrations in cystic fibrosis patients aged above 4 years: A cross-sectional evaluation. Biological Trace Element Research. 2007, 119(1):19-26.

van Caillie-Bertrand M., de Bie'ville F., Neijens $H$. Kerrebijn K., Fernandes J., Degenhart H. Trace metals in cystic fibrosis. Acta Paediatr Scand. 1982, 71(2):203-7.

van Stekelenburg G.J., van de Laar A.J., van der Laag J. Copper analysis of nail clippings. An attempt to differentiate between normal children and patients suffering from cystic fibrosis. Clin Chim Acta. 1975, 59(2):233-40.

Varkonyi A., Boda M., Szokefalvi-Nagy Z., Nyilasi B. Determination of hair trace elements in childhood celiac disease and in cystic fibrosis. Acta Paediatr Hung. 1992, 32(2):159-65.

Vormann J., Gunther T., Magdorf K., Wahn U. Mineral metabolism in erythrocytes from patients with cystic fibrosis. Eur J Clin Chem Clin Biochem. 1992, 30(4):193-6.

Ward K.P., Arthur J.R., Russell G., Aggett P.J. Blood selenium content and glutathione peroxidase activity in children with cystic fibrosis, coeliac disease, asthma, and epilepsy. Eur J Pediatr. 1984, 142(1):21-4.

Weaver C., Sorenson R.L., Kobienia B. Nonenzymatic isolation and culture of adult islets from atrophic pancreata of copper-deficient rats: a morphologic analysis. In Vitro Cell Dev Biol. 1988, 24(2):108-16.

Yadav K., Singh M., Angurana S.K., Attri S.V., Sharma G., Tageja M., Bhalla A.K. Evaluation of micronutrient profile of North Indian children with cystic fibrosis: a casecontrol study. Pediatr Res. 2014, 75(6):762-6. 


\title{
МАКРО- И МИКРОЭЛЕМЕНТЫ ПРИ МУКОВИСЦИДОЗЕ
}

\begin{abstract}
Анастасия Дикий
Тронхейм, Норвегия

РЕЗЮМЕ: Муковисцидоз - заболевание, обусловленное мутацией одного гена, поражающее многие органы. Вследствие кишечной мальабсорбции у пациентов с муковисцидозом нарушается всасывание некоторых микронутриентов, таких как макро- и микроэлементы. Большинство исследований показывают сниженную концентрацию селена и железа в крови при заболевании; в ногтях отмечается повышенное содержание меди и пониженное цинка, а содержания магния повышено в волосах. Однако изучение концентраций этих элементов показывает противоречивые результаты. Возможно, это связано с тем фактом, что всего несколько исследований было проведено на больших группах пациентов, также показатели могут варьироваться из-за отсутствия учета возраста и этнической принадлежности. В связи с этим должно быть проведено крупномасштабное исследование по изучению обмена различных макрои микроэлементов при муковисцидозе. Это позволит поддерживать обмен веществ пациентов путем коррекции комбинацией макро- и микроэлементов с целью улучшения их здоровья.
\end{abstract}

КЛЮЧЕВЫЕ СЛОВА: муковисцидоз, микронутриенты, макроэлементы, микроэлементы, дисбаланс, нарушение обмена веществ. 